\title{
N.F.S. Grundtvig, S.T. Coleridge - The Hymnwriter and the Poet
}

\author{
By David Jasper
}

Both Grundtvig and Coleridge lived into an old age which granted them the status of the sage. In 1872, Edmund Gosse graphically described the ninety-year old Grundtvig:

„For a man of ninety, he could not be called infirm: his gestures were rapid and his step steady. But the attention was riveted on his appearance of excessive age. He looked like a troll from some cave in Norway; he might have been centuries old.

From the vast orb of his bald head, very long strings of silky hair fell over his shoulders and mingled with a long and loose white beard. His eyes flamed under very beetling brows, and they were the only part of his face that seemed alive, for he spoke without moving his lips. His features were still shapely, but colourless and dry, and as the draught from an open door caught them, the silken hairs were blown across his face like a thin curtain. While he perambulated the church with these stiff gestures and ventriloquist murmurings, his disciples fell on their knees behind him, stroking the skirts of his robe, touching the heels of his shoes. Finally, he ascended the pulpit and began to preach; in his dead voice he warned us to beware of false spirits, and to try every spirit whether it be of God. He laboured extremely with his speech, becoming slower and huskier, with longer pauses between the words like a clock that is running down. He looked supernatural, but hardly Christian.«

(Two Visits to Denmark. 1911)

Almost half a century earlier, Thomas Carlyle had described Coleridge, the 'Sage of Highgate', in The Life of John Sterling (1851):

I have seen many curiosities; not the least of them I reckon Coleridge, the Kantean metaphysician and quondam Lake poet. I will tell you all about our interview when we met. Figure a fat, flabby, incurvated personage, at once short, rotund, and relaxed, with a watery mouth, a snuffy nose, a pair of strange brown, timid, yet earnest-looking eyes, a high tapering brow, and a great bush of grey hair, and you have some faint idea of Coleridge. He is a kind good soul, full of religion and affection and poetry and animal magnetism. His cardinal sin is that he wants will. He has no resolution. He shrinks from pain or labor in any of its shapes. His very attitude bespeaks this. He never straightens his knee-joints. He stoops with fat, ill-shapen shoulders, and in walking he does not tread, but shovel and slide. My father would call it "skluiffing.« $\mathrm{He}$ is always 


\begin{abstract}
busied to keep, by strong and frequent inhalations, the water of his mouth from overflowing, and his eyes have a look of anxious impotence. He would do with all his heart, but he knows he dares not. The conversation of the man is much as I anticipated - a forest of thoughts, some true, many false, more part dubious, all of them ingenious in some degree. But there is no method in his talk: he wanders like a man sailing among many currents, whithersoever his lazy mind directs him; and, what is more unpleasant, he preaches, or rather soliloquizes. He cannot speak, he can only tal-k (so he names it). Hence I found him unprofitable, even tedious; but we parted very good friends, I promising to go back some evening - a promise which I fully intend to keep. I sent him a copy of "Meister «, about which we had some friendly talk. I reckon him a man of great and useless genius: a strange, not at all a great man.
\end{abstract}

The comparison is illuminating. Grundtvig a prophetic figure, almost Godlike beyond the Christian. Coleridge, the embodiment of his own mazy thoughts, philosophizing and endlessly talking even beyond the edge of comprehension. Both seem barely within the world which, in their different ways, they so profoundly affect. They have become, in a way, worlds in themselves.

Coleridge has been the object of my study for many years. Grundtvig has taken a place in my reading only very lately and then, of necessity, through translations and English commentaries. Although some extraordinary similarities as well as profound differences between the two men have struck me, I remain distrustful of my impressions of Grundtvig. What I offer, therefore, is a series of reflections on Coleridge as one of the major intellectual, theological, and poetic figures in and beyond English Romanticism, and compare them with a reading of one of Grundtvig's hymns, thinking of both men as at once, and interconnectedly, religious and poetic.

Perhaps most obviously, both men had an almost unparalleled range of intellectual and theological interests; both were, in Coleridge's term 'library cormorants', yet equally they never lost sight of the practical necessities of existence. For Coleridge, such practical necessities could not be separated from an intense absorption in epistemology and theories of knowledge ('I reverence Immanuel Kant with my whole heart and soul', he once wrote), which, in turn, arose out of the underlying theological implications of both his poetic and his speculative activities. Richard Holmes, in his brilliant new biography of the young 
Coleridge, has recently indicated how the early »conversation « poems continually move beyond a young poet's natural interest in the problem of personal 'authenticity' to questions of whether life - or literature - can have real meaning without some form of Divine continuity or assurance within the structure of reality. Does language itself ultimately depend on the notion of Divine articulation within the universe? From whence does its power arise? (Richard Holmes Coleridge. Early Visions. London, 1989, p. 320. See also, George Steiner, Real Presences. London, 1989).

I cannot imagine Coleridge experiencing anything like the spiritual breakthrough after crisis that Grundtvig seems to have achieved in 1810. While Grundtvig in 1811 begins to search for new poetic assurance in the Bible and the history of the Church, Coleridge (never a historian in any sense, and metaphysician to the core) continues to live reflexively within the visions of romanticism. I doubt if Coleridge could have written a hymn if he tried, given the public, communal and metrical demands of hymnody. (see, C. Thodberg \& A.P. Thyssen (ed.), Tradition and Renewal p. 29).

On the other hand, like Grundtvig, Coleridge, at least as a young man, was a remarkable preacher. The sermons which Grundtvig preached between 1811-1813 in Udby must have been very different from Coleridge's Dissenting and Unitarian sermons of the 1790's, yet their effect may have been in the end not dissimilar. Classical in structure, profoundly biblical in their language and poetry, Grundtvig's sermons, it seems to me, are passionately and morally practical in their exhortation to his contemporaries. Coleridge, also, with all the radical fervour of youth, never strays far from biblical language and imagery in sermons »precociously peppered with Politics«, as he himself put it. (Holmes, p. 108 and Letters). For, Coleridge never fell into the position of imagining that an uncritical Christianity or religious orthodoxy would guarantee right belief or behaviour. The truth, closely pursued and poetically realized, was what above all mattered to him; as he crisply put it in the late work Aids to Reflection (1828):

He, who begins by loving Christianity better than Truth, will proceed by loving his own Sect or Church better than Christianity, and end in loving himself better than all. 
Christianity must efficiently work in the world; hence Coleridge's deep moral and political concerns. Hence also, as in Grundtvig's thought, his careful reflections on the relationship and distinctions between church and state and the role of education in the religious life of the nation all seen within the greater formal realm of poetry and universal questions. Like Grundtvig, Coleridge was acutely aware of the need to distinguish between temporal and eternal truth, and the nature of moral and political action considered obliquely within this distinction.

Unlike Grundtvig, however, Coleridge never actively engaged in political life. Nor was he an ordained minister of any church. He was, however, a brilliant journalist, continuing in his occasional political essays and leaders a sensitivity to contemporary issues with an uncanny sense of the relationship between the immediate and universals. As he put it in a letter written in June 1817 to the Prime Minister, Lord Liverpool, always »the whole is prior to the parts « (Ben Knights, The Idea of the Clerisy. Cambridge, 1978, p. 41). National health depended upon not simply the immediate exercise of political practicalities and negotiations, but a broadly based »dynamic philosophy«, a speculative philosophy. I sense that in both Coleridge and Grundtvig, in different ways, a reaction against eighteenth century rationalism, and the influence of Romanticism engendered in both men a lasting quality of active combination, the »esemplastic « ability to draw together into unity vastly disparate elements in a multiplicity of immediate concerns. There is a remarkable similarity within the Romantic tradition between the ambivalent poetics of Coleridge's great poem 'Kubla Khan' and Grundtvig's Christian definition of the poet in the draft of the Foreword to his collection of poetry Saga (1811) (Tradition and Renewal. pp. 29-30). Coleridge's poetic mind hovers between activity and passivity, between perception as creative and receptive, energetic and participatory. (Kathleen Wheeler, The Creative Mind in Coleridge's Poetry. London, 1981, pp. 31-3.). Grundtvig describes the types of the passive and active poet, and between them a third type which he calls the 'deponent' as a union of a passive form and active meaning. Such a poet scrutinizes and shapes his imagination with intellectual, shaping energy, before submitting to its 
processes and flights. For both men, to perceive poetically is both to create and to submit.

What I wish to establish initially, therefore, is a series of similarities between these two very different sages, and proceed now to focus specifically upon them as poets as a way of suggesting a fundamental unity within the Christian tradition and, equally, a profound theological distinction which makes of one a great Romantic poet and the other a great hymnwriter. Coleridge in his later years, in his Letters, Notebooks and particularly the posthumously published Confessions of an Inquiring Spirit (1840) presents an increasing sense of the genius of Calvin »in his best works « (Letter to Thomas Boosey Jr. 25 February 1818), as he in an intense privacy $\gg[$ groans] under a deep sense of infirmity and manifold imperfection «. (Confessions Letter I). Throughout his life as a poet is revealed the tension between the necessity, in human sinfulness, of what Coleridge describes in 1815 as 'modern' Calvinism, and the activity of the poet who reveals in fragments those glimpses of Paradise which make it bearable. Grundtvig, on the other hand, in his »unparalleled discovery « of Christian conviction in 1823-4, is settled firmly within the insights of Luther, in their understanding of the living word of the Bible and the interconnection between Word and Sacrament. (see, A.M. Allchin, »The Hymns of N.F.S. Grundtvig«. The Eastern Churches Quarterly XIII Nos. 3 \& 4. (1959) 131-2). His insights are altogether more ecclesiological, more communal and more conducive to hymnody's poetry of the congregation than Coleridge could ever achieve: but not necessarily more Christian. Both, perhaps, are poetically necessary.

I want to spend the rest of my time looking in some detail at two poems, one (perhaps Coleridge's greatest) "Kubla Khan « (1798) and the other Grundtvig's Sunday hymn, »We are God's house of living stones« (»Kirken den er et gammelt hus «. Den Danske Salmebog. no. 280), as an illustration of what I have been saying.

Notoriously, from Coleridge's prose preface to the poem, 'Kubla Khan' is a fragment of an opium dream which was interrupted as 
the poet slept in 'a lonely farm-house' by a person 'on business' from the nearby village of Porlock, who detained him for more than an hour and scattered his visions.

\section{KUBLA KHAN}

In Xanadu did Kubla Khan

A stately pleasure-dome decree:

Where Alph, the sacred river, ran

Through cavern measureless to man

Down to a sunless sea.

So twice five miles of fertile ground

With walls and towers were girdled round:

And there were gardens bright with sinuous rills, Where blossomed many an incense-bearing tree; And here were forests ancient as the hills, Enfolding sunny spots of greenery.

But oh! that deep romantic chasm which slanted Down the green hill athwart a cedarn cover! A savage place! as holy and enchanted As e'er beneath a waning moon was haunted By woman wailing for her demon-lover! And from this chasm, with ceaseless turmoil seething, As if this earth in fast thick pants were breathing, A mighty fountain momently was forced: Amid whose swift half-intermitted burst Huge fragments vaulted like rebounding hail, Or chaffy grain beneath the thresher's flail: And 'mid these dancing rocks at once and ever It flung up momently the sacred river. Five miles meandering with a mazy motion Through wood and dale the sacred river ran, Then reached the caverns measureless to man, And sank in tumult to a lifeless ocean: And 'mid this tumult Kubla heard from far Ancestral voices prophesying war!

The shadow of the dome of pleasure 
Floated midway on the waves;

Where was heard the mingled measure

From the fountain and the caves.

It was a miracle of rare device,

A sunny pleasure-dome with caves of ice!

A damsel with a dulcimer

In a vision once I saw:

It was an Abyssinian maid, And on her dulcimer she played, Singing of Mount Abora.

Could I revive within me

Her symphony and song,

To such a deep delight 'twould win me,

That with music loud and long,

I would build that dome in air,

That sunny dome! those caves of ice!

And all who heard should see them there,

And all should cry, Beware! Beware!

His flashing eyes, his floating hair!

Weave a circle round him thrice,

And close your eyes with holy dread,

For he on honey-dew hath fed,

And drunk the milk of Paradise.

(1798.)

There is good evidence to suggest that the account of the poem's origin in the cottage near Porlock on Exmoor is an ironic, shrewd literary device of Coleridge's own making, the person on business an indicator that the finite, busy world will always put bounds upon infinite vision. Yet a »dim recollection « (Coleridge's Preface. Line 30) remains, and that is enough to draw the reader back to the fragment of poetry with its mysterious indications of a vision that can never be fully recovered. The tomorrow is always yet to come. That 'Kubla Khan' is a fragment may be a deliberate exercise of the imagination, necessarily incomplete and fragmentary, but, as Coleridge understands it, a repetition in the finite mind of the poet of the infinite act of divine creation. (Biographia Literaria Chap. 13). 
'Kubla Khan' foreshadows the theological and religious concerns of the older Coleridge. It begins with a paradise garden decreed by an emperor who is threatened by the past of his 'ancestral voices'. But the paradise which is threatened by Original Sin is found again by the poet and his vision which he has but to remember in order to re-create an image of the harmony and wholeness of the Paradise with which the poem concludes. In 1815, Coleridge wrote to the poet William Wordsworth that he hoped his poetry would have "affirmed a Fall of some sense, as a Fact, the possibility of which cannot be understood from the nature of the Will, but the reality of which is attested by Experience \& Conscience« (30 May 1815 Letters). For Coleridge, the task of the poetic imagination is a theological one, 'reviving' the symphonic vision and rebuilding Kubla's dome; paradise lost and regained.

Despite the oriental barbarism of its imagery, 'Kubla Khan' remains firmly within the structural plot of the Judaeo-Christian tradition. It has frequently been pointed out that actually Coleridge is drawing on Plato, and particularly the Ion, with his images of the poet who draws milk and honey from rivers in paradisal gardens as their souls fly from flower to sweet flower. (e.g. Elisabeth Schneider, Kathleen Raine). But this is not to deny his 'divine inspiration', since it is through the poetic imagination that Coleridge reaches up to and begins to articulate the theology which becomes so necessary for him. As a poet, his theology is 'recognized', and not imposed.

In 'Kubla Khan', Coleridge prompts reflection in the reader by an interplay between a number of perspectives or visionary centres. In the last stanza, for example, he switches from first person to third person narrative; the poet with flashing eyes and floating hair, mysteriously and divinely inspired, is distanced from the visionary (in the first person) who deliberately recollects and re-creates what once he saw. Different again is the dry and ironic third person narrative of the prose Preface. The effect of these parallel levels of perspective is to prompt the reader to reflect creatively upon his own reading, to perceive that his own limited vision and reductive rationality will supply a person from Porlock to cut short the 'dream' which is released and completed only when, in the third stanza, the imagination and creative pow- 
ers assume command and the poet is received in holy fear and reverence, and the vision becomes a religious experience.

It is not accurate to describe as is often done, 'Kubla Khan' as being about the act of poetic creation. Rather, as a deliberate fragment, it has as its subject the poet's consciousness of his process of creation. He is looking at his language, what it is doing to him and what he is doing to it. The perceptual process is obviously not a response to an observed, external language. The lush descriptions are rather the transformation of subjective, internal experiences into public objects. For as the language becomes active in the processes of reading, its metaphor of mental process is drawn back in a new, creative and imaginative experience. That which the poem describes would not be were it not for the poem as-it-is-read.

The prose preface to 'Kubla Khan', with gentle irony, shakes the reader out of a literal reading of the poem which fails to perceive that the dream and the fragments are metaphors for what is happening to him. While the heightened consciousness of the poet may find, paradoxically, in his creative activity, a release by language from language, so that it may begin to intimate what is not there, a glimpse of Paradise or the tomorrow which is yet to come. (The phrase is borrowed by Coleridge from Theocritus).

I have suggested that the poetics of 'Kubla Khan' are ambivalent - hovering between activity and passivity - between the sunny dome and the icy caves, the fertile sacred river and the lifeless ocean. In his essay 'On Poesy or Art', written much later, probably about 1818, Coleridge describes artistic creativity as both passive and active on 'unconscious activity' and also 'according to the severe laws of the intellect'. It is, he suggests, 'the co-ordination of freedom and law'. From such creative activity alone can we be led closer to the nature of God, for the fragment which is the conscious intellect creates the impulse to move beyond the broken form to an infinity, so that, in a sense, the poem never really ends.

Coleridge never developed a strong sense of the historicity of the Christian tradition, nor of the community of the church. His was essentially an intensely private religious sensibility into which he was led by the formal enclosed and reflexive world of his po- 
etry: from this was forged, with its moments of creative vision, the strict and disciplined belief of Coleridge's last years, lived under the awareness of his own sinfulness and infirmity.

Grundtvig, it seems to me, develops his poetic, similarly ambivalent or 'deponent', from the opposite perspective. He was essentially a churchman and his hymns serve the public worship of the Christian community. Their poetic virtue lies not in intense introspection, but in fulfilling beautiful congregational expectation in the lively rehearsal of applied doctrine. If in Coleridge one moves through the poetry to belief, in Grundtvig one moves from belief into a durable poetry. I am hampered by having to use an English translation, but here is a hymn of Grundtvig which is a joyous statement of God's grace in the risen Christ:

We are God's house of living stones,

Builded for His habitation;

He through baptismal grace us owns,

Heirs of His wondrous salvation;

Were we but two His name to tell,

Yet, He would deign with us to dwell,

With all His grace and His favour.

Here stands the font before our eyes,

Telling how God did receive us;

Th'altar recalls Christ's sacrifice

And what his table doth give us;

Here sounds the word that doth proclaim

Christ yesterday, today the same,

Yea, and for aye our Redeemer.

Grant then, O God, where'er men roam,

That when the church bells are ringing,

Many in Jesus' faith may come

Where He His message is bringing:

I know mine own, mine own know me,

Ye, not the world, my face shall see:

My peace I leave with you. Amen.

(From Kenneth Stevenson, Jerusalem Revisited, Washington D.C. 1988 pp. 98-9). 
In almost every respect Grundtvig's hymn is the opposite of Coleridge's poetry. If, in Coleridge, all comes from deep within in a willed creation dependent hardly at all upon the memory or reproduction of actual scenes or objects experienced, in Grundtvig everything is architectured from outside. Not a solitary but a communal experience, taking its common expression from the familiar images of the Bible, from theology and from the sacraments of the Church. As Grundtvig points out in a letter, it was »a chief failing with our Fathers, which we their children must try to correct, that they wished to deal with our Saviour each for himself and to possess him, which can never be the case, as the 'Our Father' among other things should have taught them «. (Allchin. p. 135).

Not only the community, theology and literature of the church, but its physical presence in the act of worship in its buildings - font and altar - is drawn into the poetic celebration. From their physicality we are drawn back to the memorial and anamnesis of the Passion and the eternal presence of Christ in history. Coleridge's poem is outside time: Grundtvig's hymn draws all time together. In each case we are brought to rest in the moment of the verse.

In the third stanza of the hymn, the temporal dimension is replaced by the spatial, which, in its turn, is drawn into the poetic moment. The gathering is completed in the Gospel words of Christ himself, and his final blessing in words also familiar from the church's liturgy. And in each poem we are brought to the still point of Paradise itself - one in the total absorption of the reader into the mysterious experience of reading and "pure imagination «, the other in the mystery of communion with Christ realized within the diverse resources of the hymn. The poem of Coleridge and the hymn of Grundtvig share, it seems to me, an elusive quality, an indirectness and metaphorical quality which is both biblical and most profoundly poetic.

I am, of course, conscious of the limitations of reading and understanding of Grundtvig because of my lack of Danish and what strike me as on the whole rather flat translations of his work into English. Coleridge, however, as the subject of my doctoral thesis and a full-length book, has been a part of me for very many years. Nevertheless, I am prepared to say that I am 
struck by the similarities between these two extraordinary, manysided and deeply religious men, and how these are reflected in two very different kinds of poetry which they wrote. In his essay 'Grundtvig the Hymnwriter' (Tradition and Renewal. pp. 160-96), Christian Thodberg describes how, in the hymns, „the theological and poetic motives multiply, even though he always remains within his own universe of words and images«. (p. 189).

As I have suggested, Coleridge and Grundtvig have in common a passionate concern for immediate, political and practical matters, while at the same time they are poets and literary, library men. They create a universe in language, from imagination and deeply felt matter of belief. It is the power of that literary universe which make Coleridge and Grundtvig so important, for it is a power to reflect indirectly and discretely a world and change a world. It is not the limited, literal quality of language whose referentiality is direct and simple. It is, rather, that literariness which denies the immediate presentation of thought or exercise of practicalities, but is dynamic to change and unsettle, in the very act of reading, in the activity of singing. 